\title{
Predictive method of inventory optimization in industrial manufacturer performance
}

\author{
O.V. Makarova ${ }^{1, *}$ \\ ${ }^{1}$ St.Petersburg University, Graduate School of Management
}

\begin{abstract}
Strong collaboration in supply chain at B2B market may improve operational and financial performance of both suppliers and clients. Need for collaboration benefits realization is especially actual for supplying manufacturers with huge investments in inventory as well as high ordering and carrying costs. Traditional stock level optimization models rely on historic data which makes them inefficient when supply if influenced by changing customized demand of key B2B clients. Strong collaboration with key clients, synchronization of planning process through the whole supply chain up to the end user and a forwardlooking demand adjustment $(\Delta \mathrm{D}, \%)$ to the forecasting model are suggested to improve efficiency of planning. The model is validated at the B2B industrial manufacturer with positive effect. Application of the demand adjustment reorients the whole inventory planning practices towards a proactive approach that lead to a higher operational and financial efficiency.
\end{abstract}

\section{Introduction}

Inventory management, being part of working capital management, is an essential area where considerable potential for operational efficiency improvement could be found [1], [2], [3], [4]. Related to primary processes in value chain that employ critical amounts of financial recourses, even minor inventory management discrepancies may lead to huge extra costs resulted from keeping either too much or too little inventory, or from clients complains and may influence dramatically overall company's financial performance [5], [6], [7].

Though inventory management as an area of working capital management is quite a popular subject for academic studies, most of researchers analyze its influence on company's financial performance and profitability looking backwards and using data from the past for future predictions [8], [9], [10]. Companies need to revalue stock control challenges and practice and turn to more predictive approach to succeed in stock optimization and better performance [11], [12], [13]. Unfortunately, existing practice and methods of stock optimization and planning are based on «dead» data collected in accounting. Thus, it's less and less useful for contemporary operational production management oriented to satisfy increasingly individualized clients requests [14] and support highly customized approaches in B2B industrial segments which is nowadays become relevant to production of consumer goods as well [15], [16].

\section{Materials and Methods}

Some methodologists already discuss implementation of forward-looking methods for inventory predictive planning, however they most based on the "ideal market" presumption where the fact that companies do not function alone is neglected and the irrational behavior or non-equal collaboration effects are not considered [11], [17]. So, especially in customized operations with material-intensive production, inventory management becomes not just a part of working capital management, but it's essential nature with critical importance for short-term efficiency and survival [18]. Thus, collaboration in supply chain should be considered and utilized for introducing proactive planning methods for optimum stock level that expect to improve operational and financial performance [12].

Modern researchers point high impact of supplier collaboration with key clients on operational and financial performance [19] especially for B2B companies, where collaboration aims to achieve their processes cross-controlled and synchronized [11]. So, one can expect collaboration to serve better predictivity and quality of production planning while making management practices rather proactive than reactive. The research proved that profitability of manufacturing companies can be increased if managers efficiently reduce the number of days inventories held [3]. By efficient reduce here we mean to minimize both ordering and carrying costs while providing strong in-time supply of production materials. Companies should avoid inventory level being inadequate or excessive as it leads

\footnotetext{
* Corresponding author: o.v.makarova@gsom.spbu.ru
} 
to profitability decrease or stock-outs that pull back sales operations [5].

Advanced inventory managers should direct their efforts to find methods of reducing lead-time and demand driven variances, to strengthen relationships with vendors and suppliers, to improve accuracy of their predictions, as well as combining different risk sources in a supply chain [7]. Existing stock planning activity is commonly based on the traditional statistical (backlooking) approaches employed at $\mathrm{ABC}-\mathrm{XYZ}$ analysis, safety stock level, service level, reorder point, EOQ [20], [21], [22]. As studied by Ruiz-Torres and Mahmoodi [16], who focused on method that can set off changes in safety stocks levels, historical data analysis that lies under inventory planning models turned out to be not sufficient, while stock level depends on the volatility of future demand.

Collaboration typology in supply chain suggested by Holweg [23] employed forward-looking technics for inventory management (Fig.1) and opened a room for predictive tools application that could also be useful within traditional decomposition of supply chain collaboration on vertical (with customers \& suppliers) and horizontal (with competitors) ones. Vertical collaboration refers to collaboration with customers and suppliers [11].

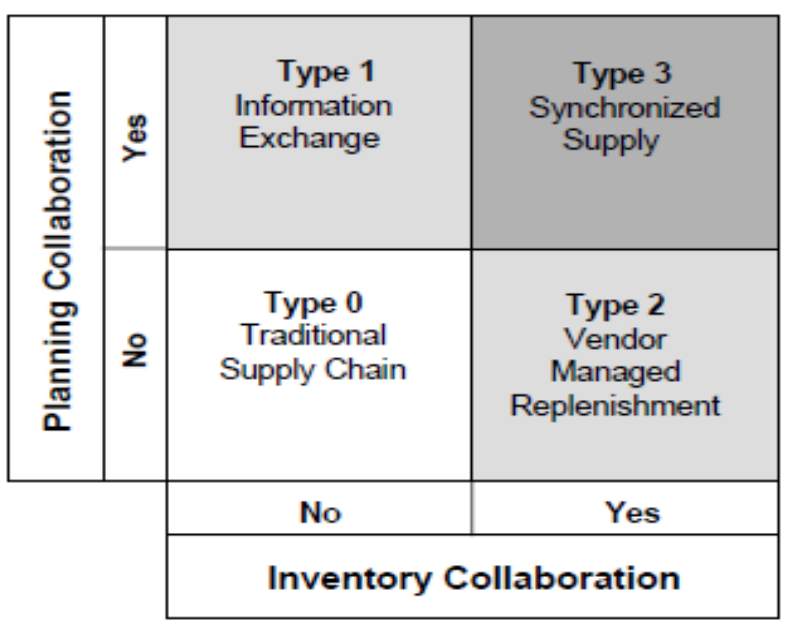

Fig. 1. Basic supply chain configurations for collaboration. Source: [23].

Despite its high importance for B2B manufacturers, collaboration shouldn't be an ultimate requirement for every partner as this activity increases fixed costs and requires extra administration. Instead, suppliers should limit its collaboration only to the cohort of key strategic clients with continuous increase of its share. Proper composition of this cohort of high influencers in supply chain is critical as their impact on turnover, level of inventory and whole operational efficiency is dramatic. It's necessary to assure that benefits and savings on inventory-production synchronization cover additional administrative expenses required.

Classic approach to optimum stock level calculation is based on historic data models [6], [8]. Where it applies well for FMCG companies that operate on B2C market, this back-looking approach provides more drawbacks than benefits for B2B producers, who may benefit from close collaboration with their key clients. So, B2B manufacturers are recommended to apply predictive analysis instruments and establish proactive inventory management that lead to additional cost savings. So, procurement departments at manufacturers should take into account not just company's production cycle, but also the client's production forecasts, and even the clients' sales forecasts, i.e. even expected end-users demand (Fig.2). The company should tend to have a predictive and synchronized collaboration where processes are interconnected [23].

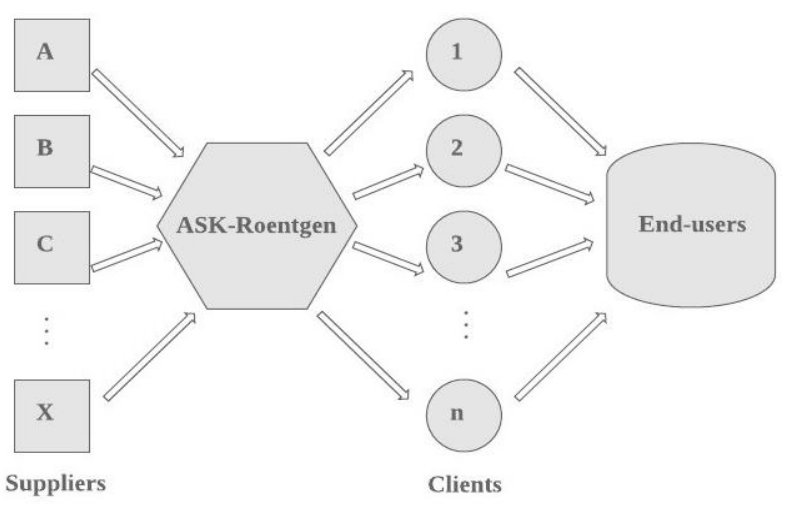

Fig. 2. Supply chain collaboration for proactive inventory planning in B2B production. Source: author.

Manufacturer should obtain a highly reliable prognosis and realistic and valuable cost saving evaluation that complies with value chain philosophy. the expected percentage of planned increase or decrease in demand $(\Delta \mathrm{D}, \%)$ should be considered. This adjustment has a lot of common to the standard deviation parameter, but while the latter is a back-looking index, adjustment on demand change turns the whole inventory planning model to address the future inventory flow. Incorporation of $\Delta \mathrm{D}$ requires usage rate, standard deviation, EOQ, reorder point and safety stock to be adjusted individually to berry change in demand. As a result, the final optimal balance to be held and evaluation of realistic cost savings will be different from the ones calculated within the back-looking inventory optimization model. Relatively, one can expect more precise evaluation of future inventory ordering and carrying costs.

\section{Results and Discussion}

The approach described above was approbated at one of the supply branches of the company that is an exclusive official GE Measurement \& Control Solutions representative in EMEA region. The subsidiary operated at B2B market, had 17 clients in 2019 where its mission was to support local manufacturers with high quality equipment, spare parts, service and consumables that contribute to final products quality improvement. Adjustment on demand $\Delta \mathrm{D}$ was estimated based on 10 key local clients ( $90 \%$ of overall turnover) that planned to increase own production and relative supply. $\Delta \mathrm{D}$ applied to optimal stock evaluation model. Overall 
Table 1. Cost savings. Inventory optimization model without adjustment on demand (back-looking).

\begin{tabular}{|c|c|c|c|c|c|c|c|c|c|c|c|c|c|c|}
\hline & 28 LUZ & EB96A & 27178 & 3zUrv & 3ZUVP & \begin{tabular}{|l|l|} 
HNLYY & \\
\end{tabular} & 3ZUWR & HNNKDU & $35 \mathrm{TBN}$ & 36540 & 38WRN & 35TAL & 28 TSU & 3ZUPC \\
\hline $\begin{array}{l}\text { Optimal } \\
\text { balance }\end{array}$ & 1,585 & 1,704 & 492 & 377 & 248 & 332 & 159 & 401 & 883 & 46 & 411 & 663 & 58 & 74 \\
\hline $\begin{array}{l}\text { avg. } \\
\text { monthly } \\
\text { inv. level } \\
\text { held }\end{array}$ & 1,884 & 1,990 & 1,594 & 915 & 462 & 697 & 466 & 1,100 & 1,918 & 265 & 1,047 & 1,686 & 146 & 161 \\
\hline$\Delta \mathrm{Q}_{2}$ & 298 & 286 & 1,102 & 538 & 214 & 364 & 307 & 698 & 1,035 & 218 & 636 & 1,023 & 88 & 86 \\
\hline $\begin{array}{l}\text { Ordering } \\
\text { costs }\end{array}$ & 242.45 & 182.17 & 163.60 & 169.49 & 154.29 & 89.35 & 161.73 & 48.17 & 18.71 & 222.60 & 27.68 & 14.51 & 124.97 & 102.14 \\
\hline $\begin{array}{l}\text { Carrying } \\
\text { costs }\end{array}$ & 32.80 & 25.26 & 22.94 & 23.68 & 21.78 & 13.66 & 22.71 & 8.51 & 4.83 & 30.32 & 5.95 & 4.31 & 18.11 & 15.26 \\
\hline $\begin{array}{l}\text { Money } \\
\text { tied in } \\
\text { inv. }\end{array}$ & 73,100 & 52,630 & 182,337 & 92,299 & 33,363 & 32,962 & 50,179 & 34,140 & 19,779 & 49,109 & 17,918 & 15,211 & 11,107 & 8,895 \\
\hline Total & & & & & & & $\epsilon 6$ & 029 & & & & & & \\
\hline
\end{tabular}

Table 2. Cost savings. Inventory optimization model with $\Delta \mathrm{D}$ adjustment (forward-looking).

\begin{tabular}{|c|c|c|c|c|c|c|c|c|c|c|c|c|c|c|}
\hline & 28LUZ & EB96A & 27178 & $3 z u r v$ & 3ZUVP & HNLYG & 3ZUWR & HNIKDU & 35 TBN & $3 W 540$ & 38WRN & 35TAL & 28 TSU & $3 Z U P C$ \\
\hline $\begin{array}{l}\text { Optimal } \\
\text { balance }\end{array}$ & 1,862 & 2,001 & 578 & 442 & 292 & 390 & 187 & 471 & 1,037 & 54 & 483 & 779 & 68 & 87 \\
\hline $\begin{array}{l}\text { avg. } \\
\text { monthly } \\
\text { inv. level } \\
\text { held }\end{array}$ & 1,884 & 1,990 & 1,594 & 915 & 462 & 697 & 466 & 1,100 & 1,918 & 265 & 1,047 & 1,686 & 146 & 161 \\
\hline$\Delta Q_{2}$ & 22 & -12 & 1,016 & 473 & 170 & 306 & 279 & 628 & 881 & 210 & 564 & 907 & 78 & 73 \\
\hline $\begin{array}{l}\text { Ordering } \\
\text { costs }\end{array}$ & 242.45 & 182.17 & 163.60 & 169.49 & 154.29 & 89.35 & 161.73 & 48.17 & 18.71 & 222.60 & 27.68 & 14.51 & 124.97 & 102.14 \\
\hline $\begin{array}{l}\text { Carrying } \\
\text { costs }\end{array}$ & 32.80 & 25.26 & 22.94 & 23.68 & 21.78 & 13.66 & 22.71 & 8.51 & 4.83 & 30.32 & 5.95 & 4.31 & 18.11 & 15.26 \\
\hline $\begin{array}{l}\text { Money } \\
\text { tied in } \\
\text { inv. }\end{array}$ & 5,272 & $-2,160$ & 168,117 & 81,029 & 26,600 & 27,716 & 45,629 & 30,719 & 16,834 & 47,288 & 15,897 & 13,491 & 9,834 & 7,551 \\
\hline Total & & & & & & & 6493 & 816 & & & & & & \\
\hline
\end{tabular}

savings on stock optimization were evaluated for both approaches (Table 1,2).

The research showed that initially (in historic data approach, Table 1) evaluated cost savings were too optimistic while optimal balance to low to satisfy the risen future demand. If company disregarded its customers planning process but rather applied inventory management models based on it's own data from the past, it won't be able to supply efficiently (in-time and with minimal costs) and profitability will suffer.

\section{Conclusion}

To have more realistic and proactive inventory planning, a manufacturing company should introduce forwardlooking adjustment on clients demand planned changes when applies traditional quantitative models to ABC$\mathrm{XYZ}$ analysis, planning EOQ, optimum stock level, reorder point, service level and other inventory planning elements where calculations based only on historic data. Companies should collaborate and work as a synchronized system to satisfy client's demand the most cost efficient way. If inventory management employs forecasting methods that look through the following supply chain over its internal production plan and consider planning conducted at clients' side useful for inventory optimization, one may name the company being proactive in its inventory management and expect high operational and financial performance results.

\section{References}

1. A.A. Nasser, The Relationship between Working Capital Management and Profitability, International Business Research, 12 (8), 142-152 (2019)

2. R. Khalid, T. Saif, A. R. Gondal, H. Sarfraz, Working Capital Management and Profitability, Mediterranean Journal of Basic Applied Sciences, 2 (2), 117-125 (2018)

3. M. Deloof, Does Working Capital Management Affect Profitability of Belgian Firms?, Journal of Business Finance and Accounting, 30 (3) \& (4), 573-587 (2003)

4. A. Nihiu, A. Dermaku, A Theoretical Review on the Relationship between Working Capital Management and Company's Performance, Acta Universitatis Danubius, 13 (3), 56-69 (2017)

5. J.P. Singh, Inventory and Working Capital Management: An Empirical Analysis, The Icfai Journal of Accounting Research, VII (2) (2008)

6. J.S. Sagner, Inventory and Working Capital Issues, In Working Capital Management: Applications and Cases (Hoboken, New Jersey: John Wiley \& Sons, Inc., 2014, 107-123)

7. I. Civelek, Sustainability in Inventory Management, Current Topics in Management, 18, 43-55 (2016)

8. G. Priniotakis, P. Argyropoulos, Inventory Management Concepts and Techniques, IOP 
Conf. Series: Materials Science and Engineering, 459, 012060 (2018)

9. F. Dooley, Logistics, Inventory Control, and Supply Chain Management, Choices, 4th quarter, 20 (4), 287-291 (2005)

10. D. Ivanov, A. Tsipoulanidis, J. Schonberger, Inventory management, Global Supply Chain and Operations Management, Springer Texts in Business and Economics, 2nd Edition (2017)

11. M. Barrat, Understanding the meaning of collaboration in the supply chain, Supply Chain Management: An International Journal, 9 (1), 3042 (2004)

12. K. Subramanian, J.B. Rawlings, C.T. Maravelias, Economic model predictive control for inventory management in supply chains, Computers and Chemical Engineering, 64, 71-80 (2014)

13. B. Tonetti, The Impact of Integrated Business Planning on Safety Stock Calculation Methods, Journal of Business Forecasting, 29-32 (2019)

14. C.Y. Lam, W.H. Ip, A Consumer Satisfaction Inventory Model for Supply Chain Integration, Expert Systems with Applications 38 - An International Journal, 875-883 (2011)

15. B. Scholz-Reiter, J. Heger, C. Meinecke, J. Bergmann, Integration of demand forecasts in ABC-XYZ analysis: practical investigation at an industrial company, International Journal of Productivity and Performance Management, 61 (4), 445-451 (2012)

16. A.J. Ruiz-Torres, F. Mahmoodi, Safety stock determination based on parametric lead time and demand information, International Journal of Production Research, 48 (10), 2841-2857 (2010)

17. A. Ivakina, N. Zenkevich, Coordinating working capital management model in collaborative supply chains, Working Paper \#9 (E) - 2017 (Saint Petersburg State University, Graduate School of Management 2017)

18. J.P. Singh, Inventory and Working Capital Management: An Empirical Analysis, The Icfai Journal of Accounting Research, VII (2) (2008)

19. T. Wisniewski, Simulation Study of Inventory Management in Supply Chains, Logistics and Transport, 1 (37), 41-48 (2018)

20. M.R. Asadabadi, A revision on cost elements of the EOQ model, Studies in Business and Economics, 11 (1), 5-14 (2016)

21. J. Bulinski, C. Waszkiewicz, P. Buraczewski, Utilization of $\mathrm{ABC} / \mathrm{XYZ}$ analysis in stock planning in the enterprise, Annuals of Warsaw University of Life Sciences - SGGW, 61, 89-96 (2013)

22. D.K. Dhoka, Y.L. Choudary, XYZ Inventory Classification \& Challenges, IOSR Journal of Economics and Finance, 2 (2), 23-26 (2013)

23. M. Holweg, S. Disney, J. Holmstrom, J. Smaros, Supply Chain Collaboration: Making Sense of
Strategy Continuum, European Management Journal, 23 (2), 170-181 (2005) 